\title{
Determinants of risk factors for asthma
}

\author{
William W Busse MD \\ University of Wisconsin-Madison, Madison, Wisconsin
}

\section{W Busse. Determinants of risk factors for asthma. Can Respir J 1999;6(1):97-101.}

There are a number of risk factors for the development of asthma, including genetic and environmental components. Moreover, there is mounting evidence that a variety of genes are associated with the features of asthma, such as persistent wheezing, airway responsiveness and chronic bronchial inflammation. However, for expression of these features, other factors must also come into play. This paper focuses on the importance of environmental factors in the development of asthma, including allergens and respiratory infections. From current evidence, it appears that in subjects with the appropriate genetic make-up, infections and allergens induce a proinflammatory cytokine response that causes airway inflammation and that in turn leads to the initiation and persistence of altered airway function.

Key Words: Airway inflammation, Allergens, Cytokines, Genetics, Infections, Reactivity

\section{Déterminants des facteurs de risque pour l'asthme}

RÉSUMÉ : Il existe de nombreux facteurs de risque pour le développement de l'asthme, comprenant des composantes génétiques et environnementales. Toutefois, de plus en plus de preuves tendent à démontrer qu'une variété de gènes est associée aux composantes de l'asthme, telles qu'un sifflement persistant, une hyperréactivité bronchique et une inflammation chronique des bronches. Cependant, pour que ces composantes s'expriment, d'autres facteurs doivent aussi jouer un rôle. Le présent article se concentre sur l'importance des facteurs environnementaux dans le développement de l'asthme y compris les allergènes et les infections respiratoires. Les preuves actuelles semblent démontrer que chez les sujets qui possèdent un patrimoine génétique approprié, les infections et les allergènes induisent une réaction proinflammatoire des cytokines qui cause une inflammation des voies aériennes et qui, à son tour, va commencer à altérer la fonction pulmonaire de manière persistante.
$\mathrm{T}$ he past decade has seen a considerable advance in identifying and understanding the determinants and risk factors involved in the development of asthma (Table 1). These determinants and risk factors include the patient's genetic background, allergens that can influence the expression of allergic diseases, birth factors and environmental factors. Environmental factors include exposure to smoking (even in utero), infections and the home environment. At present, there does not appear to be one dominant factor that determines whether an individual develops allergic diseases, whether that allergic disease is associated with asthma and which fac- tors eventually lead to the development of asthma. As information from research has been uncovered, it appears that the development of asthma is a multifactorial process in which genetics, allergens and environmental factors all contribute (Figure 1). Precisely how these factors fit into the equation that results in asthma has not been fully established but is far more apparent than it was 10 years ago.

In understanding the development of asthma and associated risk factors, it is important to realize that the perception of asthma depends upon the observer. For the patient, asthma is wheezing, cough and shortness of breath. To the respira-

Correspondence: Dr William Busse, Allergy/Clinical Immunology, University of Wisconsin-Madison Medical School, J5/220 Clinical Science Center, 600 Highland Avenue, Madison, Wisconsin 53792-2454. Telephone 608-263-6183, fax 608-263-3104, e-mail wwb@medicine.wisc.edu 
TABLE 1

Risk factors or determinants of asthma

- Genetics
- Allergy
- Birth factors
- Environmental factors
Smoking
Residence
House dampness
Race or poverty
Season of year
Infection

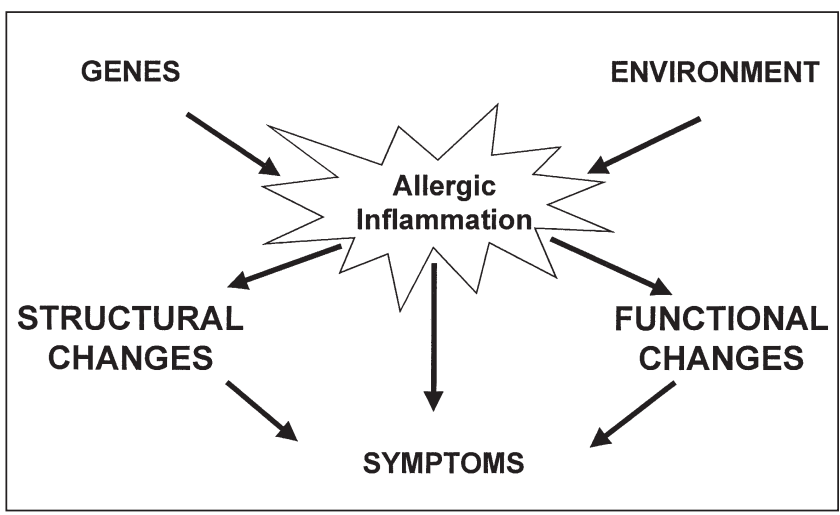

Figure 1) Interaction and inter-relationships between the genetic background and environmental factors leading to the development of asthma

tory physiologist, asthma is airway hyperresponsiveness and reversible airflow obstruction, which may not be complete. To the immunopathologist, asthma means airway inflammation.

These multiple views suggest that asthma is difficult to define with precision and inclusiveness. Nonetheless, asthma is now viewed as a disorder that is characterized by chronic inflammation of the airways in which many cells participate, particularly mast cells, eosinophils and activated, subpopulations of lymphocytes. It is felt that this chronic inflammatory process of the airway contributes to symptoms of asthma breathlessness, chest tightness and wheezing. Chronic inflammation also contributes to widespread but variable airflow obstruction that can reverse either spontaneously or as the result of treatment; the inflammatory changes also are a principal factor in the regulation of bronchial hyperresponsiveness. Consequently, airway inflammation has become a central focus in the pathogenesis of asthma and development of disease severity, and as the target of therapy.

\section{DETERMINANTS OF ALLERGIC DISEASES AND ASTHMA}

Genetics: From population studies and the ability to identify genes in association with features of asthma and allergic diseases, many new advances have been made (1). Key areas of the chromosome associated with the features of asthma, ie,

\section{Role of Allergy in Asthma}

$\begin{array}{ll}\text { Risk Factor (Inducer) } & \text { Exacerbation (Provoker) } \\ \text { House Dust Mite } & \text { Pollens } \\ \text { Cat } & \text { House Dust Mite } \\ \text { Cockroach } & \text { Cat } \\ \text { Alternaria } & \text { Cockroach } \\ & \text { Alternaria } \\ & \text { Other Molds }\end{array}$

Figure 2) Role of allergy and allergens in the development of asthma

bronchial hyperresponsiveness and allergies, have been identified. These advances were initially derived from studies of families and twins. Gene mapping studies have tried to identify areas of individual chromosomes that might link to features of asthma. Included in these discoveries is the finding of $11 \mathrm{q}$ associated with atopic disease (2). The production of a variety of cytokines, including interleukin (IL)-4, IL-5 and IL-8, has been linked to $5 \mathrm{q}$ (3). However, an 'asthma gene' has yet to be discovered. Identifying the asthma gene is complicated by the need for well-defined populations, and the need to define asthma and critical information on environmental risk factors. Advances in genetics will be important to establish those factors that 'regulate' asthma and to understand more fully the mechanisms involved in the development of this process. Moreover, information on the genetics of asthma will eventually translate into improved recognition of the disease, and possibly early diagnosis and unique therapeutics.

Role of allergens: Allergic reactions are a major factor in the development of asthma (4). This is seen in patients of all ages but is more prevalent in the pediatric population. From studies that have evaluated the role of allergic reactions to asthma pathogenesis, it has been found that allergens can be divided into those that are important risk factors (ie, inducers) versus those allergens that principally cause exacerbations (ie, provokers) (Figure 2). Allergens found to be important for the induction of asthma include house dust mite, cat, cockroach, and alternaria. For example, studies by Sporik et al (5) were able to show that the age for the onset of asthma was related to the house dust mite concentration in the patient's environment. The greater the concentration of house dust mite in the environment was the earlier the age that asthma was diagnosed. This suggests that the house dust mite is an important factor in the induction of asthma. It does not necessarily mean that house dust mites cause asthma, but rather implies that for the susceptible individual, this allergen is an important factor in the eventual expression of asthma (Figure 3).

Other allergens are also important to the development of 


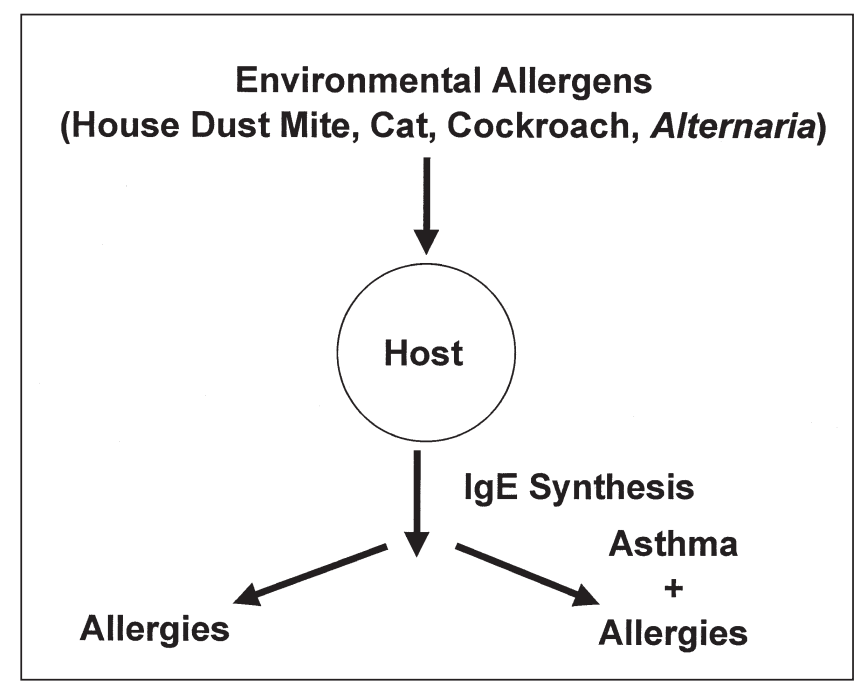

Figure 3) Role and inter-relationship of allergens in the development of allergies and asthma. Ig Immunoglobulin

asthma. Halonen and colleagues (6) at the University of Arizona found a relationship between sensitivity to alternaria and the severity of asthma. The Arizona group was able to show that the intensity of the immediate skin test response to alternaria was directly related to the frequency with which asthma was diagnosed. Thus, like house dust mite, alternaria is also an important antigen associated with asthma, and the degree of sensitivity appears important to the expression of asthma.

Environmental factors may also be important determinants in the development of asthma and allergic diseases. Before the unification of Germany, von Mutius and colleagues
TABLE 2

Changes in the prevalence of sensitivity to specific antigens

\begin{tabular}{lccc}
\hline Antigen & $\begin{array}{c}\text { Prevalence (\%) } \\
\text { 1991 to 1992 } \\
(\mathbf{n}=\mathbf{1 3 0 3})\end{array}$ & $\begin{array}{c}\mathbf{1 9 9 5} \text { to 1996 } \\
(\mathbf{n}=\mathbf{1 6 2 4})\end{array}$ & $\mathbf{P}$ \\
\hline House dust mite & 4.6 & 8.1 & 0.0002 \\
Cat & 3.3 & 3.1 & 0.7 \\
Grass pollen & 9.1 & 11.5 & 0.03 \\
Birch pollen & 8.4 & 14.2 & $<0.0002$ \\
\hline
\end{tabular}

Reprinted with permission from reference 8

(7) were able to show that the frequency of asthma and allergic diseases was greater in West versus East Germany. With reunification of Germany, the investigators (8) have evidence that a greater proportion of former East Germany children now have allergic diseases (Table 2). These data suggest that with the conversion to a more westernized society, allergic diseases become more common (9). In the same period, these investigators did not find an increase in asthma; such findings indicate that factors that determine the expression of allergies and asthma may be distinct.

\section{ROLE OF ALLERGY IN THE DEVELOPMENT OF AIRWAY INFLAMMATION}

The concept of the mechanisms governing the development of airway flow obstruction and hyperresponsiveness of asthma has also undergone considerable revision. New insights have been derived largely by identification of the cells that are involved in the allergic process, recognition of new mediators important in this process, and the capacity to define gene and gene products associated with allergic inflammation. From these studies, it is apparent that airway inflammation is a

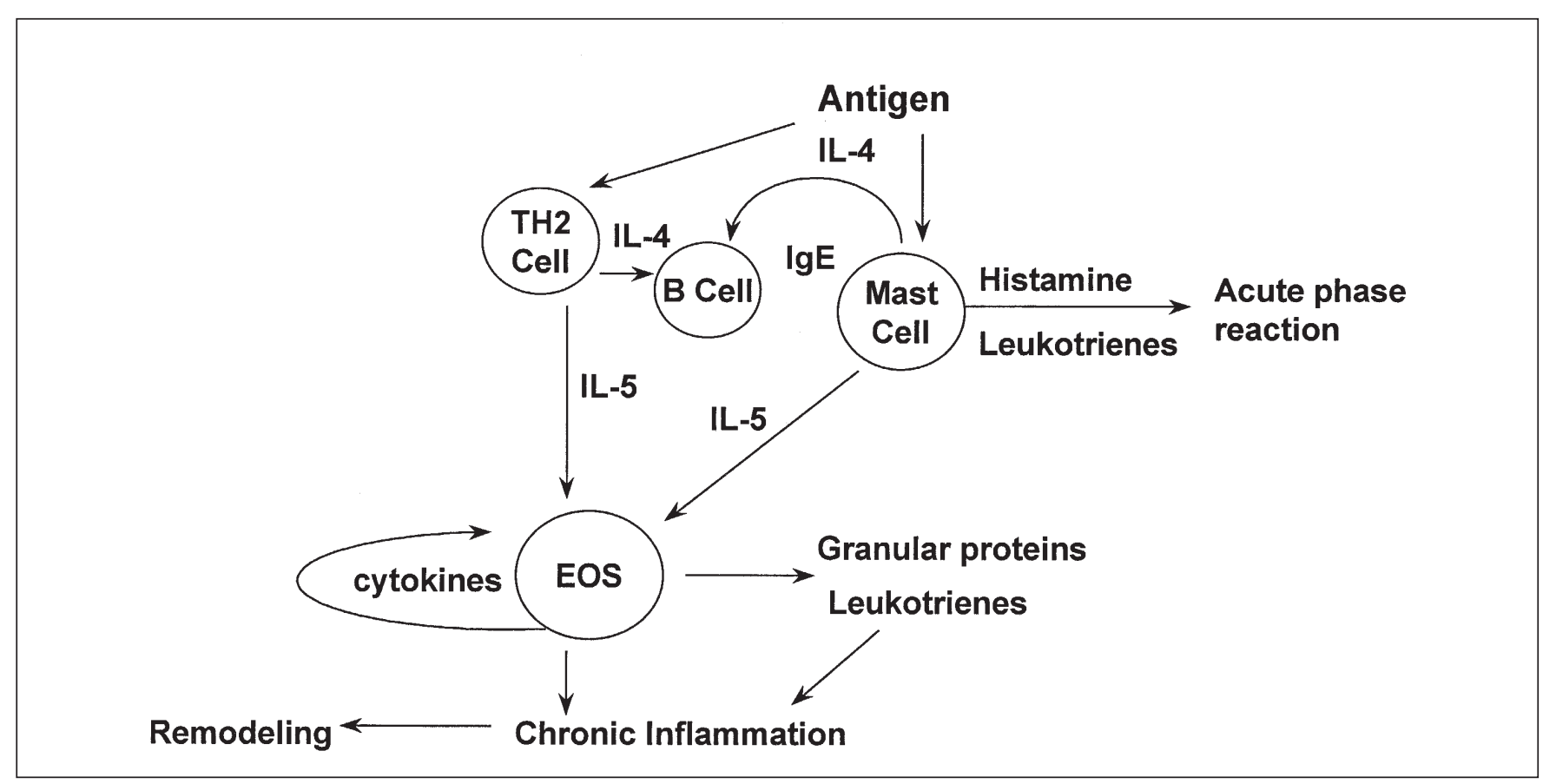

Figure 4) Orchestration of cells and mediators in the development of allergic inflammation. EOS eosinophils; IG Immunoglobulin; IL Interleukin 
defining feature of asthma, the process is very complex and the cell-cell interactions are multiple in nature (10).

The paradigms involved in the development of allergic inflammation have also expanded considerably. The inflammatory process is now viewed as a series of steps or phases that go from an immediate reaction, resulting in bronchospasm, to acute inflammation, chronic inflammation, and potentially in the development of repair or remodelling (10). The cells and cell interactions that occur are intricate, multiple mediators are involved, and the process, as to its initiation and determination, is not completely known (Figure 4). From models using antigen provocation, mast cell activation is viewed an initial event; whether it is an essential event in the process for the development of allergic inflammation is not fully understood. Mast cell activation leads to the release of histamine and leukotrienes (11). These mediators are responsible for the acute bronchospastic phase. It is also likely that this initial exposure to antigen involves activation of lymphocyte subpopulations. Stimulation of these cells leads to the generation of cytokines, including IL-4 and IL-5 (12). These cytokines are important for the recruitment and activation of eosinophils in the airway. Also participating in this process are chemokines such as eotaxin and RANTES, which, in combination with IL-5, are responsible for the recruitment of eosinophils to the airway (13).

Eosinophils appear to be the central cells causing acute, chronic and persistent inflammatory changes in the airway (14). Precisely what activates eosinophils in this process is not established. It is also not clear how resolution of the airway inflammatory response occurs or whether the acute allergic injury leads to repair with permanent damage of the bronchus. The recognition of this repair process may explain how patients with persistent asthma can develop irreversible changes in lung function. Involved in the remodelling process are mucous gland hyperplasia, smooth muscle hypertrophy, angiogenesis and collagen deposition. Understanding how it occurs and what regulates this process will be an important step forward in the control of airway inflammation.

\section{ROLE OF RESPIRATORY INFECTIONS}

The contribution of respiratory infections to asthma is important (15). In patients with existing asthma, respiratory infections are the principal cause of exacerbations. Recent data have indicated that $80 \%$ to $85 \%$ of asthma attacks are due to viral respiratory infections (16). The common cold virus, rhinovirus, is the most frequent cause of the exacerbations, some of which can be quite severe. It is proposed that intercurrent respiratory viral infections intensify existing airway inflammation and, with this, the severity of asthma. Consequently, inflammation remains the target of therapy (17).

Respiratory infections may also play an important, if not critical, role in the pathogenesis of asthma (18). Currently, the understanding of atopy and asthma, and their interrelationship is incomplete. As discussed, it is felt that the genetically predisposed individual will develop 'allergies' following an appropriate environmental exposure. What determines the onset and the severity of the process has yet to be fully determined. Moreover, it is unclear why some individuals with an allergic predisposition develop asthma and others do not.

Nonetheless, the past decade has seen insight gained into the inter-relationship between allergies and asthma. Martinez and colleagues (19) at the University of Arizona studied nearly 1000 children from birth for the presence of asthma. These investigators found approximately $50 \%$ of children by six years of age had no episodes of wheezing; the other $50 \%$ had wheezing episodes. Approximately $20 \%$ of the children who wheezed had only transient episodes of wheezing. Those with transient wheezing had low lung function at birth. This low lung function was still present when re-evaluated at six years of age; however, their episodes of wheezing were transient. It is proposed that as lung growth occurred and immunity to viral respiratory infections developed in these individuals, episodes of wheezing with infections become less frequent and eventually nonexistent.

Another group of children had 'late' onset of wheezing. These children had normal lung function at birth and continued to have normal lung function when tested at age six years. They did, however, have a history of maternal asthma and exposure to cigarette smoke early in life. A third group of children had persistent wheezing. This is a very interesting and important segment of the study population. The children had normal lung function at birth; however, when they were reassessed at age six years, their lung functions had decreased. This finding suggests that the processes involved in leading to persistent asthma may be such that irreversible changes can occur in airways. What causes these persistent changes is not established. There are data that show that early intervention with inhaled corticosteroids may modify this response. However, from these key studies, many important questions remain. Principally, what determines whether children resolve the causes of wheezing, develop late onset wheezing or go on to persistent wheezing is not defined. Nonetheless, there is evidence that some types of respiratory infections early in life, ie, those caused by respiratory syncytial virus, may be a determining factor.

Other recent data have also begun to provide insight to the role of infections and asthma. Shirakawa and colleagues (20) examined children at six and 12 years of age. They evaluated the presence of asthma and allergic disease in relationship to the child's tuberculin skin test reactivity. The investigators found that children with positive tuberculin skin test reactions at both six and 12 years of age had less allergic disease and less asthma than those with a negative response tuberculin. Furthermore, the children without allergies and asthma tended to have higher levels of serum interferon-gamma. These findings raise the possibility that a host's ability to respond to an infection by the generation of interferon-gamma may be a protective response and may tip the balance away from a $\mathrm{TH} 2$ profile. That is, if the child has a normal or vigorous interferon-gamma response to an infection, the production of IL-4 and IL-5 will be less. With low interferon- 
gamma production, the generation of IL-4 and IL-5 will be greater; with the increased production of these cytokines, allergies and asthma are more probable.

At present, it is speculated that children have a TH2 phenotype in the womb and at birth (21). This cytokine profile is necessary for fetal viability. Following delivery and growth, the child experiences bacterial and viral infections, which produce interferon-gamma. The production of interferongamma suppresses the TH2 paradigm. However, in individuals with a diminished capacity to generate interferon-gamma response to pathogens, the $\mathrm{TH} 2$ phenotype persists and, with it, comes the development of allergic disease and asthma. Although this analysis is overly simplistic in its conclusions, it does provide a new view into the mechanisms that regulate the development of allergic diseases and asthma.

\section{REFERENCES}

1. Sanford A, Weir T, Pare P. The genetics of asthma. Am J Respir Crit Care Med 1996;153:1749-65.

2. Cookson WOCM, Sharp PA, Faux JA, Hopkin JM. Linkage between immunoglobulin $\mathrm{E}$ responses underlying asthma and rhinitis and chromosome 11q. Lancet 1989;i:1292-5.

3. Marsh DG, Neely JD, Breazeale DR, et al. Linkage analysis of IL-4 and other chromosome 5q31.1 markers and total serum immunoglobulin E concentrations. Science 1994;264:1152-6.

4. Duff AL, Platts-Mills TAE. Allergens and asthma. Pediatr Clin North Am 1992;39:1277-91.

5. Sporik R, Holgate ST, Platts-Mills TAE, Cogswell JJ. Exposure to house dust mite allergen (Der p I) and the development of asthma in childhood. N Engl J Med 1990;323:502-7.

6. Halonen M, Stern DA, Wright AL, Taussig LM, Martinez FD. Alternaria as a major allergen for asthma in children raised in the desert. Am J Respir Crit Care Med 1997;155:1356-61.

7. von Mutius E, Martinez FD, Fritzsch C, Nicolai T, Roell G, Thiemann HH. Prevalence of asthma and atopy in two areas of West and East Germany. Am J Respir Crit Care Med 1994;149:358-64.

8. von Mutius E, Weiland SK, Fritzsch C, Duhme H, Keil U. Increasing prevalence of hay fever and atopy among children in Leipzig, East Germany. Lancet 1998;35:862-6.

9. Holgate ST. Asthma and allergy - disorders of civilization? Q J Med 1998;91:171-84.

10. Drazen JM, Arm JP, Austen KF. Sorting out the cytokines of asthma. J Exp Med 1996;183:1-5.

\section{SUMMARY}

The concepts of asthma have changed considerably in the past one to two decades. Airway inflammation is viewed as the major driving force in the pathogenesis and severity of asthma as well as a therapeutic target. Precisely how airway inflammation occurs is not totally known. However, with the further discovery and elucidation of genes associated with allergic disease and features of asthma, this picture will become clearer. Many factors determine the intensity of airway inflammation in asthma - allergens, infections and occupational exposures. As a consequence, airway inflammation has become a prime target of therapy in all forms of asthma. Evidence has now begun to indicate that the regulation of airway inflammation will be the most effective intervention for disease control.

11. Peters SP. Mast cells and histamine in asthma. J Allergy Clin Immunol 1990;86:642-6.

12. Robinson DS, Hamid Q, Ying S, et al. Predominant TH2-like bronchoalveolar T-lymphocyte population in atopic asthma. N Engl J Med 1992;326:298-304.

13. Zhang L, Redington AE, Holgate ST. RANTES: a novel indicator of allergic inflammation. Clin Exp Allergy 1994;24:899-904.

14. Smith H. Asthma, inflammation, eosinophils and bronchial hyperresponsiveness. Clin Exp Allergy 1992;22:187-97.

15. Folkerts G, Busse WW, Nijkamp FP, Sorkness R, Gern JE. Virus-induced airway hyperresponsiveness and asthma. Am J Respir Crit Care Med 1998;157:1708-20.

16. Johnston SL, Pattemore PK, Sanderson G, et al. Community study of role of viral infections in exacerbations of asthma in 9-11 year old children. BMJ 1995;310:1225-9.

17. Lemanske RF Jr, Dick EC, Swenson CA, Vrtis RF, Busse WW. Rhinovirus upper respiratory infection increases airway hyperreactivity and late asthmatic reactions. J Clin Invest 1989;83:1-10.

18. Openshaw PJM, O'Donnell DR. Asthma and the common cold: can viruses imitate worms? Thorax 1994;49:101-3.

19. Martinez FD, Wright AL, Taussig LM, Holberg CJ, Halonen H, Morgan WJ. Group Health Medical Associates. Asthma and wheezing in the first six years of life. N Engl J Med 1995;332:133-8.

20. Shirakawa T, Enomoto T, Shimazu S, Hopkin JM. The inverse association between tuberculin responses and atopic disorder. Science 1997;275:77-9.

21. Warner JA, Jones AL, Miles EA, Colwell BM, Warner JO. Maternofetal interaction and allergy. Allergy 1996;51:447-51. 


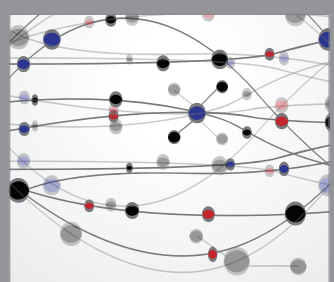

The Scientific World Journal
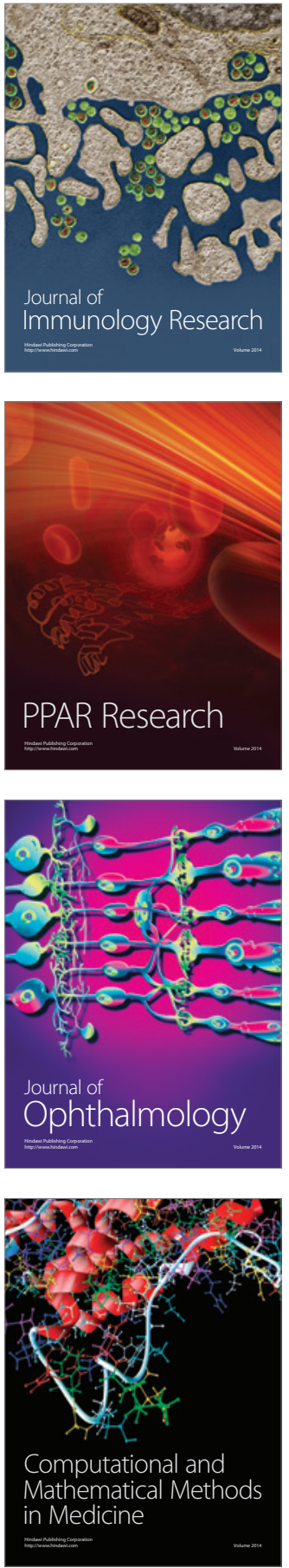

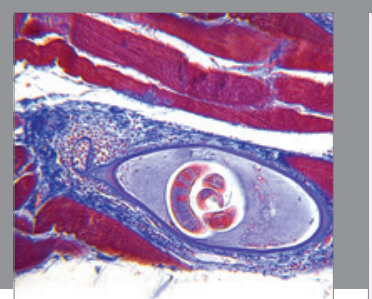

Gastroenterology Research and Practice

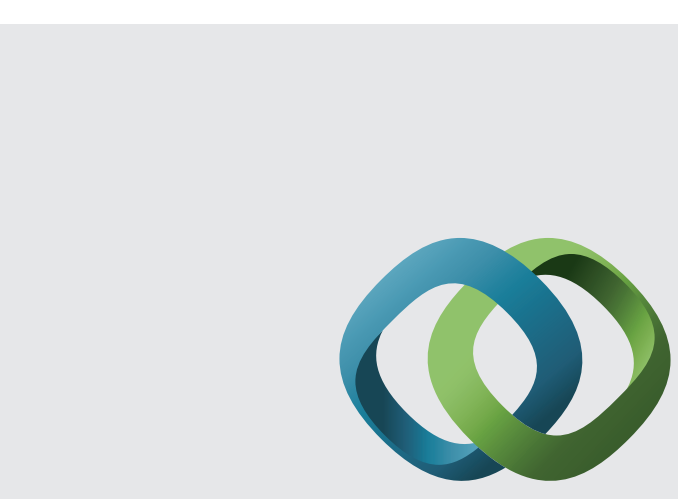

\section{Hindawi}

Submit your manuscripts at

http://www.hindawi.com
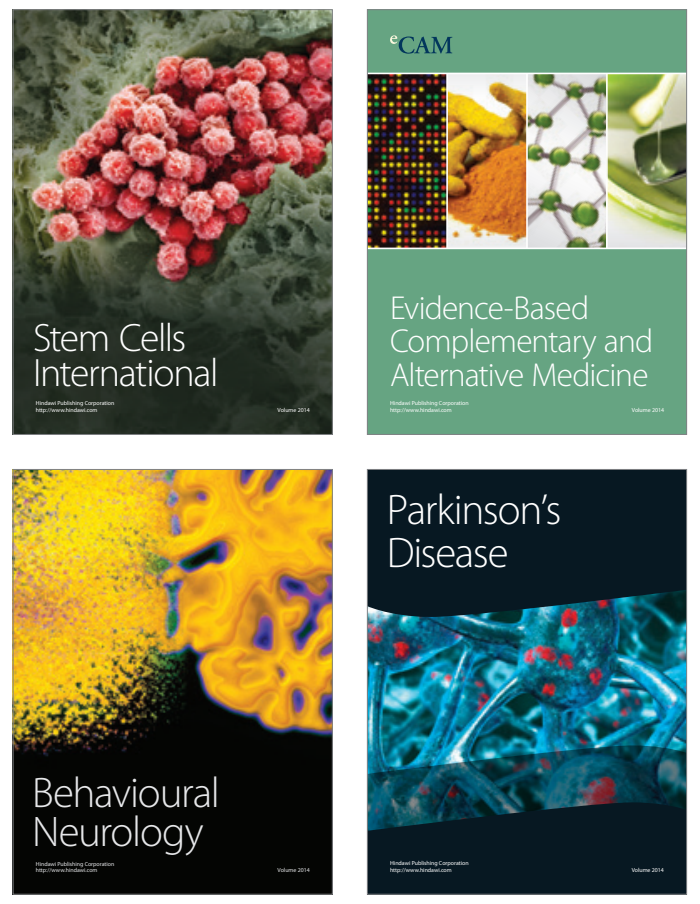
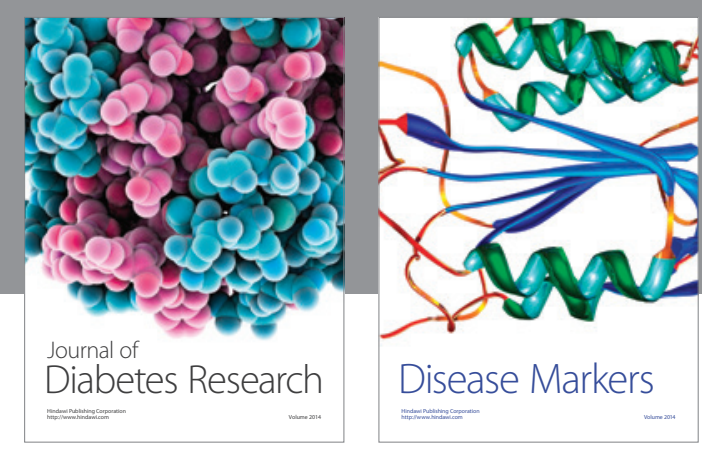

Disease Markers
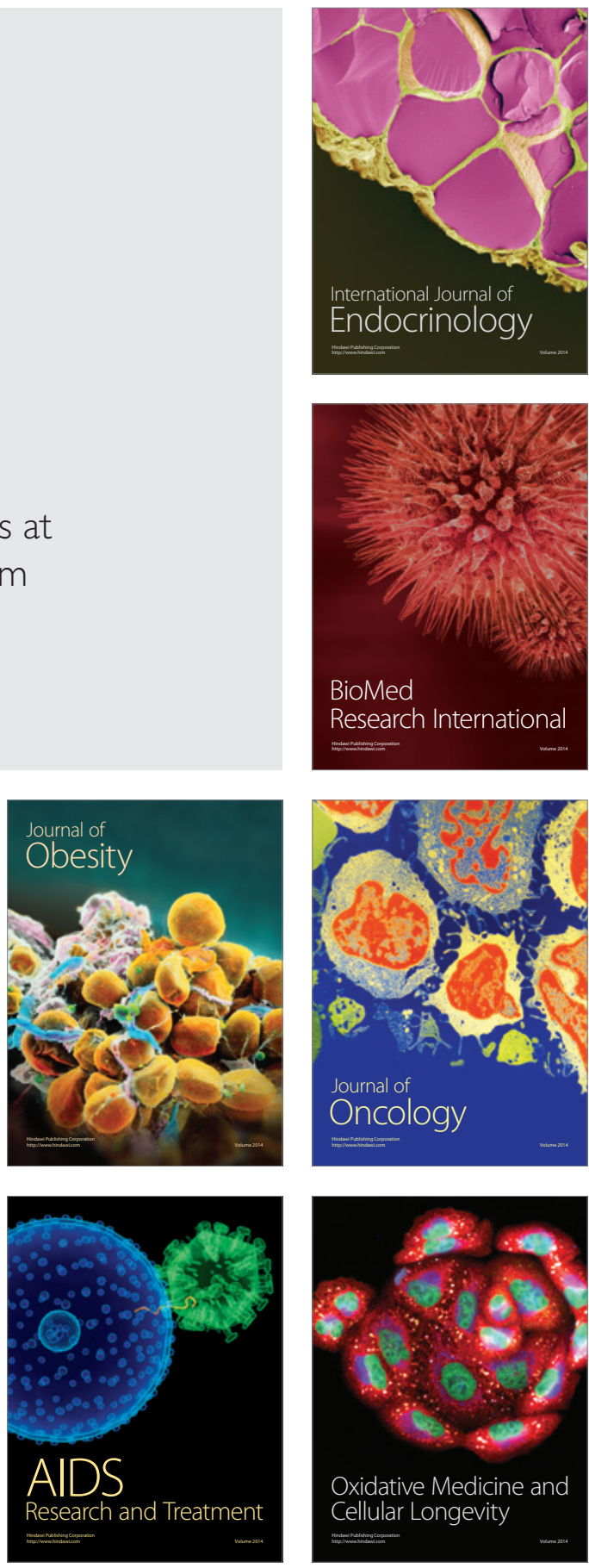